\title{
4 Is Plant Species Identification Possible in Middle English Herbals?
}

David Moreno Olalla

Universidad de Málaga

Brother Cadfael tucked up his habit and ran for the shelter of the cloister, there to shake off the water from his sleeves and cowl, and make himself comfortable to continue his reading in the scriptorium. Within minutes he was absorbed in the problem of whether the 'dittanders' of Aelfric was, or was not, the same as his own 'dittany'. Ellis Peters, The Devil's Novice (1983), Chapter I.

\section{The problem}

The transmission of the classical textual corpus during the Middle Ages was complicated because the oldest volumes that served as exemplars for the medieval manuscripts were copied and recopied at monasteries, universities and private scriptoria. The sad result was that many MSS present gibberish fragments due to the many scribal mistakes and hypercorrections that accumulated in them during the several copying processes. This is of course an academic truism, which we may call the universal cause of error as it was at work in virtually every medieval textual tradition regardless of its actual subject. But in the case of texts dealing with the Natural Sciences, and very acutely in pharmacological treatises, a second, particular cause should also be taken into account. This has to do with the fact that Western phytography, i.e. plant description, was still in its infancy, having receded rather than proceeded since Graeco-Roman times. In fact the opinions held by the likes of Dioscorides or Pliny the Elder in their fundamental treatises

How to cite this book chapter:

Moreno Olalla, D. 20I5. Is Plant Species Identification Possible in Middle English Herbals? In: Shaw, P., Erman, B., Melchers, G. and Sundkvist, P. (eds) From Clerks to Corpora: essays on the English language yesterday and today. Pp. 53-70. Stockholm: Stockholm University Press. DOI: http://dx.doi.org/Io.I6993/bab.d License: CC-BY. 
(De materia medica and Naturalis historia $)^{\mathrm{I}}$ were still taken as law without much ado fifteen centuries after they were first put down in writing.

This argumentum ab auctoritate moved in two directions. On the one hand, it seems to have hampered any real development in botanical fieldwork, and so the descriptions appearing in medieval treatises remained vague. On the other hand, the desire to interpret the Classical texts correctly led the medieval scribes to collect all possible synonyms from all accessible sources, forgetting that the same species may/will be known under different names in different places and oppositely that different species may be designated with the same name, ${ }^{2}$ which in practice meant the sloppy application of syllogisms ('A is B and B is C, therefore A is C;' in relation to this, see Moreno Olalla 2013a: 398-399). This (mis)treatment of plant-names is behind the well-known problem that it is very difficult sometimes to be certain as to the actual species being mentioned in a medieval text: more often than not, at least two or three different species are theoretically possible. Of course the problem is most acutely felt with laconical texts such as synonyma, which seldom provide a physical descriptions of the plants, but it can also usually be detected in more verbose texts such as receptaria and even medical herbals.

In the particular case of medical and botanical treatises composed in Atlantic countries such as England, the above confusion became worse, since those species that did not grow in the Mediterranean milieu were ascribed as a matter of course to plant-names already used by the Greeks and Romans. The Middle English plant-name and the Latin synonym therefore do not necessarily tally. This last hindrance is still very well alive in Contemporary English and examples abound: think for instance of the acacia, which according to the Classical evidence (MM i IOI; NH xxiv I09) probably meant a species of the genus Acacia Willd. (so García Valdés I998: 20I, fn. 20I), or perhaps some Mimosa spp. (André I956: s. v.; Simpson \& Weiner I989: s. v. acacia $^{\mathrm{I}}$ ), but which is

I These will be indicated respectively as $M M$ and $N H$ henceforward. I ignore the

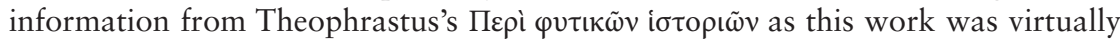
unavailable to Western scholars until its $\mathrm{I}_{4} 83$ translation into Latin (De historia et causis plantarum). Note that Dioscorides, just like Galen, was in fact best known in Western Europe through Latin translations and the works of epigones, but for the sake of convenience his work will be here quoted in the original Greek.

${ }^{2}$ Prior I863: xx mentions the well-known case of the Bluebell, which refers to Hyacinthoides non-scripta L. in England and to Campanula rotundifolia L. in Scotland-and, one may add, to sundry species in the US (Mertensia virginica (L.) Pers. ex Link, Eustoma russellianum Salisb., Phacelia campanularia A. Gray, inter alia), the Caribbean (Clitoria ternatea L.) or Australia (Wablenbergia gloriosa Lothian). 
commonly understood in English today as the Robinia pseudacacia L., a species brought from the New World (Prior I 863: I).

The outcome of all these factors is that we cannot always know for a fact which plants are really being treated by the writer of a Middle English treatise: frequently a very broad identification by genus is the nearest we can get, while in some cases we must rest content if we can identify the family to which some obscure plant-name refers. But a more precise identification by species is occasionally possible. In the following pages I intend to $(a)$ comment on problems, both medieval and contemporary, that are often encountered in connection with plant identification, $(b)$ show how the meanings usually given to plant-names in dictionaries, even in the most scholarly ones such as the Middle English Dictionary (MED), are sometimes vitiated because of those very problems and do not withstand a careful textual analysis, and hence the species provided by general lexicographical works should never be accepted at face value, and $(c)$ suggest that despite all odds, it is sometimes possible to identify the species meant by the writer-or, at least, to provide very educated guesses.

I will draw my examples from Lelamour's Herbal ( $\mathrm{LH}$ henceforward). This is a medicinal collection of 2 I 4 plant species, ${ }^{3}$ alphabetically arranged by their English names and kept in London, British Library, Sloane MS 5, ff. I3ra-57ra ( $S$ for short). Although in its explicit the piece purports to be a Middle English translation of Macer Floridus's De Viribus Herbarum made in $\mathrm{I} 373$ by an otherwise unknown Hereford schoolmaster called John Lelamour, the version preserved in $S$ was actually composed in the I46os near or in London and it is best described as an assortment of entries drawn from different ME traditions. ${ }^{4}$ It would be a moot question even to decide whether Lelamour translated some entries himself: the Rue Herbal and Agnus Castus, the two main detected sources for $L H$, were already in English in MSS older than $S . .^{5}$ Apart from the substantial number of entries, which makes it one of the most

${ }^{3}$ It would be more accurate to say that there are 2 I 4 entries but no more than 2 I I species, for at least three of them were treated twice (Moreno Olalla 2007: I 20).

${ }_{4}$ The only I 4 th-century piece in the MS is a brief botanical trilinguale (ff. $4 \mathrm{r}-\mathrm{I} 2 \mathrm{~V}$ ), which was bound together with the rest of the volume at a later date: the wear and tear and the dirt on ff. $4 \mathrm{r}$ and $\mathrm{I}_{3} \mathrm{r}$ suggest that these pages were left uncovered for quite a long time. On f. $3 \mathrm{r}-\mathrm{v}$ there is a late $\mathrm{I} 3$ th-century medical fragment in Latin on urines.

5 See Moreno Olalla 2007: I22; 2013b: 948 about the Rue Herbal. Agnus Castus was edited in Brodin I950. 
important herbals in Middle English (Hunt I989: ix), $L H$ is actually quite an average work; as is usually the case with vernacular herbals, there are no illustrations, and whenever the text provides a physical description of the species, this is by no means detailed. Broad remarks on the size and colour of leaves and flowers, and sometimes the presence of bulbs and seeds, is about all one can wish to find there. A detailed comment on the usual habitat of the species is the exception and not the rule.

I will reference my quotations from this source using a folio/line system, since $L H$ remains unpublished even though it has been known since the late I 7 th century and used as a source text since the I 84 os at least. ${ }^{6}$ It has been the subject of two theses as well. The first of them was an M.A. completed in the late thirties (Whytlaw-Gray I938), which was used by the editors of the MED. Whytlaw-Gray's editorial and lexicographical approach to the text was considered dated and inaccurate at times, and so a fresh edition, following more modern criteria, was included as part of a Ph.D. dissertation a few years ago (Moreno Olalla 2002).

\section{Scribes behaving badly: Carthnote}

I would like to begin with perhaps the most simple form of distortion: scribal mistakes and overzealousness through the ages and their modern consequences. On f. 20va/6-I9, in the section of the herbal for plant-names beginning with the letter ¿C〉, we read the following:

\section{Cidanum}

Carthnote, that is an erbe that hape levis like to fenell and wip flouris and smale stalkys. He growip in wodis, also in medis. The vertu of this erbe is pis: that, and he be stampid and laid to a sore, he will feche a-wey all dede fleshe and helpipe renewe the quyck fleshe. Also stampe this erbe and put him to bat place pat lackip here: he shall restore hit a-gayne with-in schorte tyme of plaster layeng.

According to MED (Kurath et al. I954-200I: s. v.), carthnote is a hapax legomenon vaguely defined there as '[s]ome medicinal plant'. It is certainly possible to go further than that just by reading the whole entry: the text itself provides us with several clear clues, beginning with

\footnotetext{
${ }^{6}$ Sloane 5 was catalogued already in Bernard r697: ii.25 I. To my knowledge, $L H$ was first quoted in Halliwell-Phillipps I 889: i.xx. The excerpt chosen was the entry Mowsere, i.e. Mouse-ear (Hieracium pilosella L.). The MS was also perused by contributors to the NED/OED, as witnessed by several quotations contained therein (see Moreno Olalla 2007: I I9 for a list of entries).
} 
the accompanying Latin heading. Cidanum is not recorded in any text or glossary I know of, but Cidamum is (the faulty reading in $S$ can be easily explained as a scribal misreading/mispelling of the original cluster of minims). This word appears in another important medical herbal, Agnus Castus (AC henceforward), which offers almost a twin entry of $S$, although it also provides a collection of synonyms that is missing in $L H$ : 'dilnote or slyte or haylwourth' (Brodin I950: 216).

The lists of synonyms provided in $A C$ and other sources such as Alphita (see next paragraph) make it clear that cidamum must be taken as a mistake for "Ciclamen, while carthnote is obviously another error, for "earthnote this time (cf. AC corhnote < OE eordnut) due to the Lombardic initial $\langle\mathrm{E}\rangle$ in the exemplar, which probably had a round shape. Cyclamen was used to refer to the name-sake genus and especially to the Sow-bread (C. purpurascens Mill.), and indeed both virtues of carthnote mentioned in $S$ (against wounds and alopecia) are also reflected in Dioscorides's account of the Sow-bread (MM ii I 64).

Still, there is an important detail in the English text that seems to gainsay this identification: according to Dioscorides 'the cyclamen has

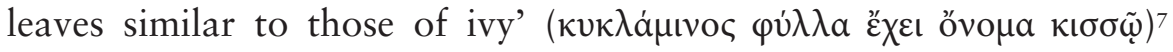
while the author of $L H$ wrote that '[e]arthnote [...] hape levis like to fenell'. The connection between both texts can, nevertheless, be maintained. Cf. the following definition from Alphita: '[c]iclamen uel ciclamum, sive citeranum, panis porcinus, malum terre idem. angl. dilnote' (Mowat I 887: 39). The synonym panis porcinus restitutes the lost link between both texts again, cf. '[p]anis porcinus, ciclamen, malum terre idem. a[nglic]e dilnote uel erthenote' (Mowat I887: I34). The identification of erthenote with cyclamen is assured as well by the translation of the original L. succum ciclaminis as 'pe Iuse of erpenote' in the Cyrurgie of Guy de Chauliac (taken from Kurath et al. 1954-200I: s. v. èrthe).

Yet another problem remains, not only in $L H$ but in many medieval texts including Alphita or AC. OE eorpnut did not refer to the Sowbread, but was an umbelliferous species, identified as some Bunium sp., especially the Earth-chestnut (B. ferulaceum Sibth. \& Sm.), or else the Pig-nut (Conopodium majus (Gouan) Loret $=$ B. flexuosum Stokes). This is confirmed by the explicit mention of the similarity of this species with dill and the resemblance of its leaves to those of fennel. I think that the confusion between both plants ultimately lies in a mistaken

\footnotetext{
7 Translations from Greek are my own.
} 
reading in $\mathrm{NH} \times \mathrm{xx} 2 \mathrm{I}$, where Pliny confused the Greek plant-name ßovviác (L. napus = OE næep) with ßoúvıv (L. bunium = OE eorpnut; see André 1956: s. v. nāpus). Napus, on the other hand, was also called rapum in some Post-Classical sources; and finally, rapum was also a name for cyclamen (vid. André I956: s. vv. cyclamı-nos, nāpus, rāpum). The tiresome scribal thirst for synonyms, which is so frequently encountered in medieval glossaries, equated both plants even though they were clearly distinguished in the Classical literature. The misidentification seems to have passed unnoticed to scribes perhaps because all those plants present a big edible bulb which swine craved after. ${ }^{8}$

As a short excursus, I would like to highlight here that misreadings are not peculiar to medieval scribes only, but are shared by modern researchers and unsuspectingly transmitted by serious scholarly works sometimes. Drawing from $L H, M E D$ includes an entry ara-wort, which is laconically defined as '[a] Flowering plant of some kind', and even given a tentative etymology: '[c]p. wort plant, \& ?arwe arrow'. The word is presented as a hapax taken from the entry Pes columbe (probably, the Soft Cranesbill, Geranium molle L.) in LH: 'Coluyr-fote is an herbe, his levis bep like to araworte'. This should in fact be put down as a ghost entry, for it is due to a faulty reading by Whytlaw-Gray that crept into the dictionary. The manuscript actually reads «Maworte, i.e. some Mallows (Malva sp.). Comparison of the flowers of the Cranesbill with those of the Mallows

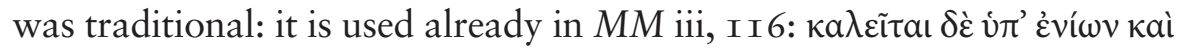

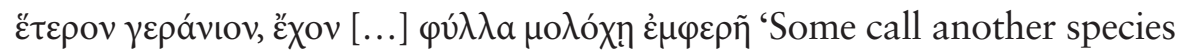
"Cranesbill”, one that has [...] leaves like those of the Mallows'.

${ }^{8}$ This also explains why several fungi of the genus Tuber L. (i.e. the truffles), the arachis, etc. were also called 'earth-nut'. Already in NH xxv I I 4, rāpum, tūuber and cyclaminos are said to be similar plants, providing with an early instance of quasi-confusion between them. This mistake was transmitted to the late OE Durham Glossary of the names of worts, which seems to be the first instance in English where cyclaminos is equated with some plant different from the Sow-bread: 'Cyclaminos, Eortheppel, slite, attorlathe' (Cockayne I864-I866: iii-30I). Judging from the English names (see Bosworth \& Toller I898: s. v. átorlápe), the Cyclamen was apparently confused here with the Mandrake. Note that the Mandrake was called malum terrae (André r956: s. v. mandragoras), but this name was also applied to the Cyclamen sp. (André r956: s. v. cyclaminos), thus providing a bridge between both plants: cyclamen <---> malum terrae <---> mandragoras. 


\section{Habits die hard: Horse-pistill}

Another common mistake in modern works is to accept uncritically the identification of a ME plant-name suggested traditionally or on the basis of a single scholarly work, even though the context in another treatise may be against that equation. On f. $22 \mathrm{vb} / 28-23 \mathrm{ra} / \mathrm{s} 8$, for example, we can read the following:

\section{Endiuia}

Endyue ys an erbe that som men callip horse-pistill. Dis erbe hape prykkys with-oute. Pe lefe ar longe and when he is brokyn he dropip mylke, and he hape a litell yelow flour and his sede blawip a-waye with pe wynde as dope dent de lyon. The vertu of him is pis: take pe juis pere-of and medill hit with hote water and drynke hit, and pat helip be stoppinge of pe mylte and pe lyuer. Also pis erbe is gode $\mathrm{y}$-dronke for be jaundys and for be feuer tercian and for pe hote postem. Also bis erbe a-swagith pe grete hete of pe lyuer and of be stomake, for he is colde and moiste.

In Present-day English, Endive is a common name for two species of Chicory, a family of Compositae (Cichorium spp.): C. intybus L., indigenous to Europe, and C. endivia L., which was imported from China as early as the I6th century. Obviously only the former could fit in here; but the description does not fit at all: C. intybus bears bright blue flowers, ${ }^{9}$ and its leaves do not have 'pricks', as stated in the text.

The editor of $A C$ (Brodin I950: 22I), a text which shares this entry with $L H$, was evidently aware of the impossibility of accepting a Cichorium species, so in the accompanying glossary he suggested, perhaps on account of the yellow flowers, that the plant intended here might be some wild lettuce, Lactuca virosa L. or else L. scariola L. This identification was accepted by $M E D$, where the text of $L H$ is actually quoted (Kurath et al. I954-200I: s. v. thistel n., sense b). Still, this identification should be rejected since the general look of these species is not reminiscent of a thistle at all, see Figure I for details. ${ }^{\text {Io }}$

Again, reading closely the physical description provided in the actual ME text-which is uncharacteristically detailed-will not go unrewarded. The comparison of this species with a thistle, implicit in the ME designation and explicit in the mention of a dandelion, and the colour

9 'Blue daisy', 'blue dandelion', 'blue-sailors' are modern synonyms for this species.

10 The engravings used in this chapter were taken from Bauhin I598, and kindly provided by the Missouri Botanical Garden. 


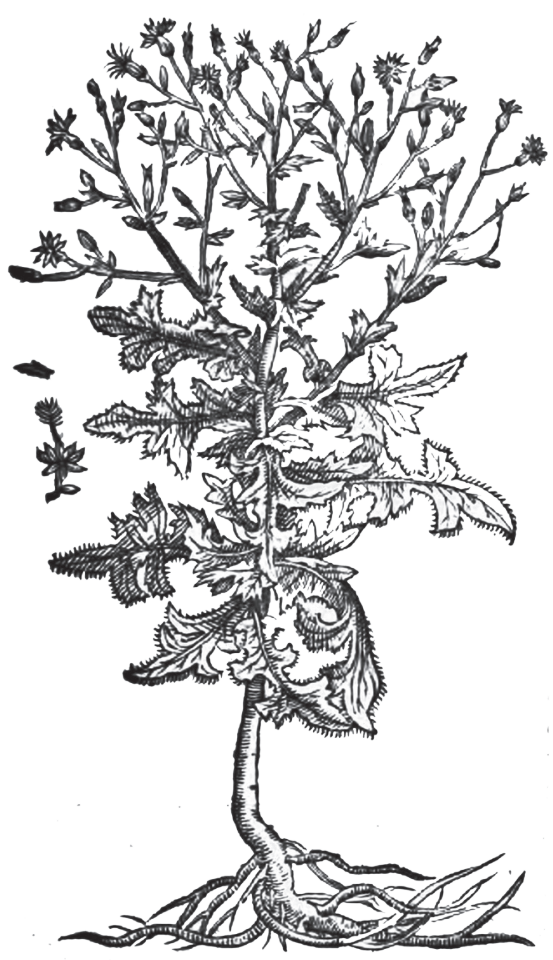

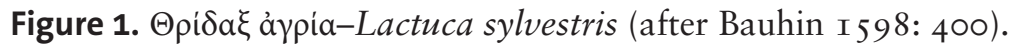

of the flowers make me think that the plant actually intended here may well be some Helminthotheca sp., a genus akin to Cichorium that normally displays yellow flowers. There is one species in particular of this genus, the Bristly Ox-tongue (Helminthotheca echioides (L.) Holub) that fulfills the physical description in $L H$ quite well. Its leaves and bracts are noticeably covered with white bristles that very much resemble small 'prikkys', just like any other Liguliflorate Composite this species yields a white latex when the stem is broken ('when he is brokyn he dropip mylke'), and its pappused achenes are easily blown away with the wind ('his sede blawip a-waye with pe wynde'). It is interesting also to note here that the distribution of this plant in Britain seems to be the south-west counties (Martin I965: 50), and this is exactly the same area where, to judge from the linguistic evidence, the text may have been originally composed (Moreno Olalla 2007: I 26-I32). Since the description of the species seems not to have been recorded in the Classical literature, could this support the hypothesis that the author of $L H$ did some field work after all? 


\section{One size fits all: Affodil}

I would like to stress further the pitfalls of accepting uncritically the meanings provided by modern lexicographical works through the case posed by the species called Centum capta in the Latin heading and affodill in the ME text. The fragment where this plant is described in $L H$ (f. I4va/I-29) runs as follows:

\section{Centum capta}

Affodill is an herbe pat beripe a faire yolewe floure and at pe toppe he hape ronde coddys, in pe whiche he berith sede and his levis beth smale and longe. The vertu of him is that pe branchis of this erbe ben gode to hele pe dropesy. Also drynke pe juis of pe flourys of the $[\mathrm{s}]^{\text {II }}$ erbe in wyne and that will sle byting of venymous wormys. Also take be more of this erbe and pe juis of his leuys and a litell safar, lat this boyle to-gadrys with swete wyne streyned fayr: hit is gode for renynge eyen. Also be more j-brent and made to pouder temper bat with a litell oyle, a-noynte that place wher that lackyth here and hit shall make hit to growe a-yene. Also, and a harde sharpe clope be wette in pe juis of this erbe, let rubbe the morfue with that clope and hit shall fall a-way, for this erbe is hote and drye in the secund degre.

At least three different species from three different genuses can be proposed as the plant referred to here, depending on which authority we accept. MED (Kurath et al. I954-200I: s. $v$. affodil, sense a) states that this plant-name normally stands for the Ramsons (Allium ursinum L., also called Wild, Bear or Wood Garlic; an image is given below as Figure 2), and provides thirteen illustrative quotations. The meanings 'asphodel' (sense $b$, three quotations, two of them taken from synonyma) and 'rhododaphne' (sense $c$, a single quotation) are preceded by a question mark, which denotes that these senses are uncertainall in all a sensible editorial policy: we have just seen how compilers were not too particular when it came to the gathering of synonyms and so, their equivalences should be taken with a big pinch of salt. In the same vein, Tony Hunt identified three Allium spp. as the species behind Latin "Centum Capita": A. ursinus, A. vineale L. (Crow Garlic) and A. schoenoprasum L. (Chives). It is worth mentioning that, even though other ME synonyms are given in Hunt's glossary (ramese, crowgarlyk, wilde garlek, civys and maudefeloun), affodill stands out as the most usual ME plant-name to refer to this Latin species (Hunt I989: s. v.).

II $\langle$ S〉 added over the line. 


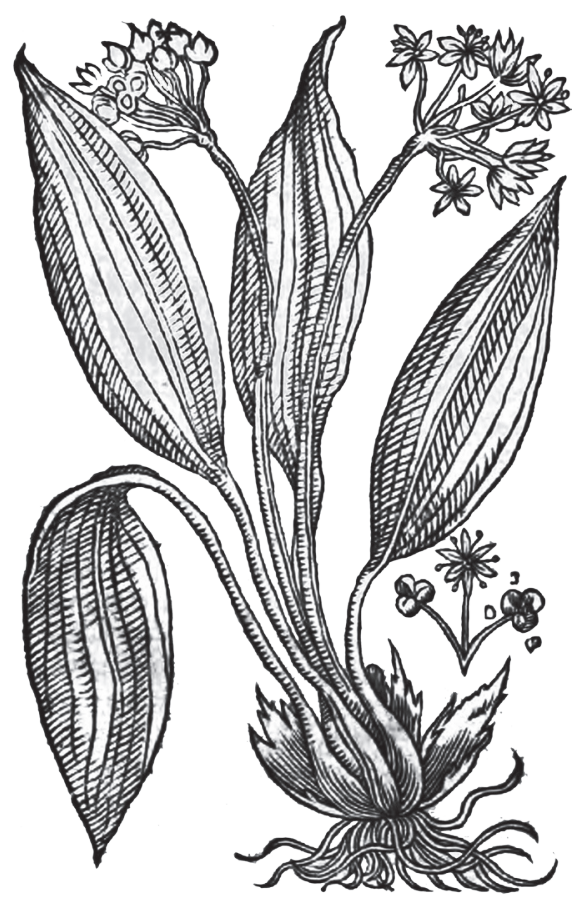

Figure 2. Allium ursinum (after Bauhin I 598: 422).

It is only natural therefore that one would assume that the entry in $\mathrm{LH}$ deals with Ramsons too.

Still, the physical description provided in the entry may point to a second candidate: the species referred to by the medieval author could also be the daffodil (Narcissus pseudo-narcissus L.; see Figure 3). Indeed, the confusion between the Asphodelus and the Narcissus species in England can be traced at least to the I550s, as recorded by William Turner in his New Herball: 'I could neuer se thys herb [ie. asphodelos, 'ryght affodill'] in England but ones, for the herbe that the people calleth here Affodill or daffodill is a kynd of narcissus' (Turner I 55 I: B.iij verso); in fact, the very word 'daffodil' is etymologically connected with 'affodill' (see Simpson \& Weiner I989: s. v. daffodil for details). This possibility is not contemplated in Kurath et al. I954-200I: s. $v$. affodil, but in view of the description and the post-medieval evidence, it may be worth speculating whether the entry in $\mathrm{LH}$ may be after all devoted to some Narcissus.

So far we have paid attention to lexicography and phytography. Yet if we turn to the list of healing properties proposed in the 


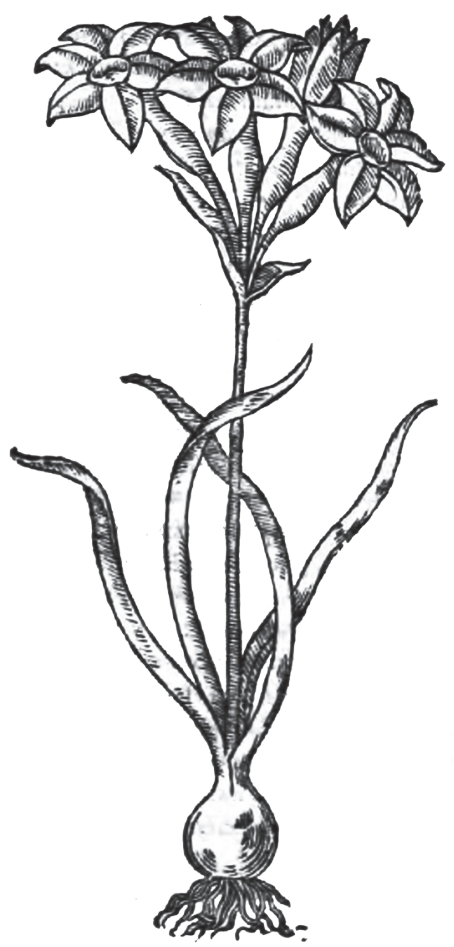

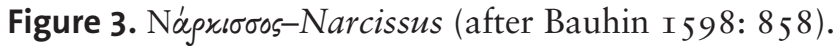

text, we will notice that the entry in $L H$ fits extremely well with the

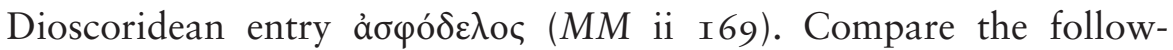

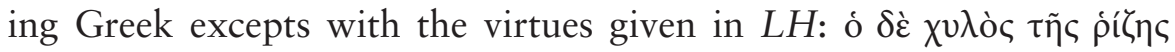

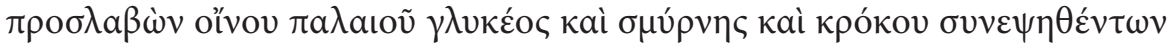

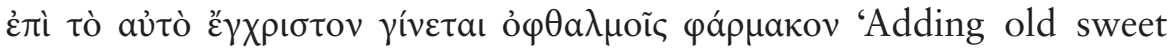
wine, myrrh and saffron to the juice of the root and boiling all together,

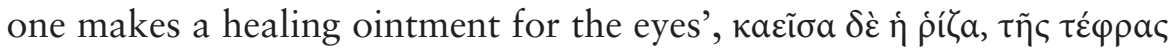

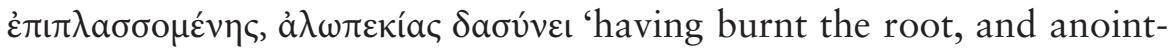
ing [the bald place] with the ash, it brings back the hair', and ả $\lambda \varphi \cos \tau \varepsilon$

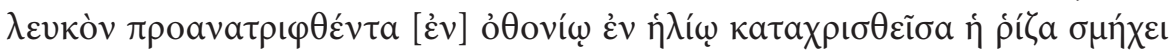
'The root, used as a salve, wipes off white leprosy if rubbed with a linen cloth in the sun'. The virtue of affodill against poison mentioned in $L H$ also appears in $M M$, although the wording is somewhat different.

The Dioscoridean species has been tentatively identified as some Asphodelus spp., perhaps A. aestivus Brot. or A. fistulosus L. (García Valdés I998: 346, fn. 208), but I think that we can attempt a 
different species identification. There is indeed a yellow-flowered species (Asphodeline lutea L.), ${ }^{\mathrm{I} 2}$ but this was at the time a native of the Eastern Mediterranean only and, as such, apparently unknown to the Classical and medieval authors. If the Latin heading in LH, Centum capta (for "capita, meaning 'a hundred heads') and the mentioning of 'ronde coddys' at the top of the stalk is taken into account, Asphodelus aestivus Brot. is a very attractive candidate (cf. the capsules at the end of the stalk of Figure 4). This is the third, and last, possibility.

Identification of the species treated in $L H$ with the Ramsons presents two almost insurmountable problems. To begin with, the general description of the plant in the ME entry is very much against this idea: the leaves of the Ramsons are long indeed, but also rather broad, as seen in Figure 2 above, while their flowers are conspicuously white. Second, the pharmacological virtues proposed for this species, which are apparently the same as those of the common garlic (Allium sativum L.; see

${ }^{12}$ See www.botanic-garden.ox.ac.uk/asphodeline-lutea.

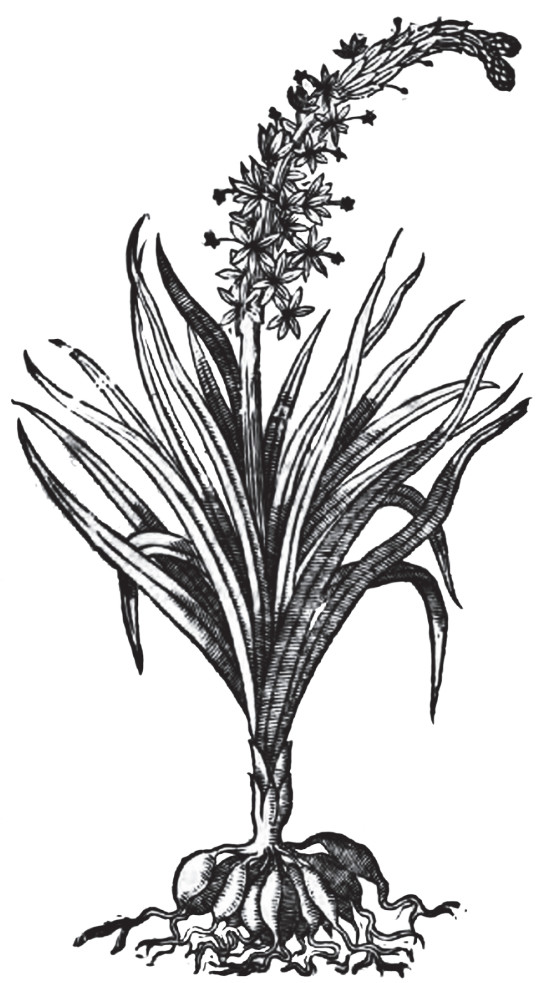

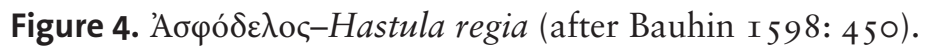


$\mathrm{NH}$ xix I I6), do not match at all with those appearing in $L H$. Since neither the physical nor the medical description favour this identification, we can, I think, safely reject this candidate $M E D$ notwithstanding. Note moreover that A. ursinum is not a Mediterranean species, and this runs counter to the other entries in $L H$, which ultimately derive from Classical sources. ${ }^{\mathrm{I}}$ We have then to decide between the daffodil (as suggested by the general physical description), and the asphodel (as suggested by the matching virtues with Dioscorides's account and, partially, also by its physical description). Two factors should be taken into account before deciding which is likely to be the actual species in the ME text.

As mentioned above, $L H$ is a compilation of several Latin sources: this means that as a rule those works by Dioscorides, Pliny or Galen were the ultimate sources of information, rather than the reflection of any personal fieldwork undertaken by Lelamour himself-or indeed any other English contemporary botanist. Therefore, that particular entry in Pliny's Natural History or Dioscorides's Materia Medica that fits the Middle English text best will probably be the plant that the original ME translator intended to describe and extol in his text. And it happens in this case that the virtues offered in the Middle English match perfectly those of the asphodel, having nothing to do with those of the daffodil, as they are given in MM iv I 58 or NH xxi I 28.

The second factor to bear in mind is purely pharmaceutical, and has to do with the chemical constituents present in those species. There is only one property of the daffodil worth mentioning: it contains an alkaloid, called narcissine after the plant, which is emetocathartic and phlogogenetic (i.e., induces vomit and causes inflammation; see Felter \& Lloyd I905: s. v. narcissus). Moreover, narcissine has strong stupefacient properties as well: cows avoid the plant, for eating it could paralyse them for some minutes (Font Quer I987: 9II). This feature was already known to the Greeks-although, contrary to NH xxi I 58 , the plant-name is apparently unrelated to the root meaning 'numbness'

${ }^{13}$ Ramsons, in fact, is not recorded in the Dioscoridean entry for Garlic (MM ii I 52 ), nor appears in Mattioli, I 558 ; the image used for Figure 2 is actually an addition by Caspar Bauhin (that is why there is no Greek name in the caption), who included it in his edition of Mattioli together with the description and an image of 'Allium Anguinum' (i.e. A. victorialis L.), another Allium sp. that he found in the Sudetes ('montes qui Bohemiam à Silesia disterminant') in I 573 (Bauhin I 598: 423). 
that we can also find in narcotic. ${ }^{\mathrm{I} 4}$ These two virtues were of course recorded in $M M$ and would not fail to appear in any medieval treatise, but they are missing in $L H$. A lacuna in the text is highly unlikely, since $A C$, which again runs parallel to $L H$ here, does not record such properties in any of the several extant MSS either.

These reasons seem to support that the asphodel (Asphodelus aestivus Brot.) is the plant treated here, but the question remains as to why the general description of the plant is that of a daffodil. Is is an addition in $L H$, or else was something taken from his exemplar? The latter is a more sensible option, if only because this is also stated in AC. The description of the plant in this textual tradition ( $16 \mathrm{I} / 26 \cdot 30$; Brodin I950: I 24-I 25) is in any case fuller and different in some minor details:

Affadilla is an herbe pat men clepe affadille or belle blome. It is lyke to lek and it hath a zelwz flour, and in be crop a round codde quanne pe flour is falle. In quyche is seed lyke to onyoun seed.

Be that as it may, the description of the plant should not be used as compelling evidence. We should never forget that the plants described by Greeks and Romans did not always grow on an Atlantic island. This is in fact a case in point: the asphodel does not grow naturally in Britain, but the daffodil does. What we have here seems to be a case of name shift: the original name is used to refer to another species, and in fact daffodil is but a by-form of an original affodil (see Simpson \& Weiner I989: s. v.). The second phase of this identification is that of virtue shift: the medicinal properties of the former are also assumed for the latter, to such a degree that the early English botanists came to think that the plant that they were then holding was the same one described by Dioscorides many centuries before.

We can logically deduce from here that the ME author's purpose was to translate the uses of the plant Centum capta, which cannot but be the Asphodel and, probably, the Asphodelus aestivus Brot., and he described physically the English plant that he honestly thought was the asphodel. He actually never intended to talk about a daffodil; had he known that the plant that he had in front of him as he was writing this entry was the Narcissus of the Greeks and Romans, not the asphodelus

I4 'A narce [i.e. vápкๆ] narcissum dictum, non a fabuloso puero.' Similar remarks can be found in Plutarch's Questiones conviviales 647b. Cf. Chantraine I999: s. $v$.

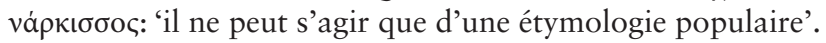


or centum capita, it stands to reason that he would have written a very different entry.

\section{Quis custodiet ipsos custodes?: Conclusions}

Is plant species identification possible in Middle English herbals? I think that for many cases the slightly disappointing answer is: 'yes, but...' Twisted textual transmissions, recurrent scribal crazes for synonyms (at least since Greek times), and misapplication of the same names and virtues to species growing in separate areas of the world but sharing some feature are conspicuous dangers in this journey. I have provided a few examples that will hopefully demonstrate that close reading can and must be instrumental for the job of defusing (albeit just partially) such minefields.

Perhaps the main problem here is that trustworthy literature on this topic is scarce in comparison with the attention paid to the same matter among Classicists (see André 1956, I958, I985; Fortes Fortes 1984a, I984b inter alios). Tony Hunt's stab at a solution (Hunt I989) must be taken as a thoroughly scholarly yet preliminary work, since he provides no discussion on the whys and wherefores that motivated his decision to equate Middle and Contemporary English plant-names. Carole Biggam's initiative, the ASPNS (Anglo-Saxon Plant Name Survey), ${ }^{15}$ and the articles by her collaborators and herself (for example Biggam I994, 2003) do hit the mark fully, but they deal by definition with Old English names only.

Historically, moreover, there has been a perceptible scholarly habit towards passing the buck and-if one is allowed to continue with clichéd idioms-leaving the proverbially drowsy dogs safely tucked inside their kennels when it comes to equating ME plant-names and the modern binomial nomenclature. While this is perhaps a bit of a foregone conclusion (see McCarren 1998 for similar caveats but with a more general scope), the examples analyzed above, which are in no way unique to $L H$ or any other ME herbal that I know of, teach us that when it comes to plant-identification we simply should never trust the information fed to us by dictionaries.

It would, however, be very unfair to put the blame on dictionaries and glossaries. We are dealing here with a lexicological, not a

${ }^{15}$ http://www.arts.gla.ac.uk/STELLA/ihsl/projects/plants.htm. The project seems sadly discontinued. 
lexicographical, problem. Therefore it is neither Tony Hunt nor the editors of the $M E D$, but their colleagues working on manuscripts, who are ultimately responsible for the current situation. In the particular case of $L H$, for instance, MED was misled by the work of WhytlawGray, which was poor by any scholarly standard. Reliable editions must be done of the many treatises, big and small alike, that still await publication on the shelves of libraries scattered over the world, while critical revisitations of those treatises already edited and discussed will be much appreciated. Text glossaries remain an absolute need in any edition indeed, but no more than ample textual and linguistic notes that should accompany them, discussing at length why the editor deems that this or that particular species is the one referred to in that particular text.

\section{References}

André, J. (1956). Lexique de termes de botanique en latin. Paris: Klincksieck.

- (1958). Notes de lexicographie botanique grecque. Paris: Honoré Champion.

- (I985). Les noms de plants dans la Rome antique. Paris: Les Belles Lettres.

Bauhin, C. (ed.) (I 598). Petri Andrece Matthioli medici Cosarei et Ferdinandi Archiducis Austrice, Opera quae extant omnia. Francofurti: Officina Nicolai Bassæi.

Bernard, E. (1697). Catalogi librorum manuscriptorum Anglice et Hibernice in unum collecti, cum indice alphabetico. Oxoniæ: Theatro Sheldoniano.

Biggam, C.P. (1994). Howenhnydele: an Anglo-Saxon medicinal plant. Botanical Journal of Scotland, 46:4, 6I 7-22.

Biggam, C.P. (ed.) (2003). From earth to art: the many aspects of the plantworld in Anglo-Saxon England. Amsterdam-New York: Rodopi.

Bosworth, J., \& Toller, T.N. (г898). An Anglo-Saxon dictionary based on the manuscript collection of the late Joseph Bosworth. Oxford: Oxford University Press.

Brodin, G. (ed.) (1950). Agnus Castus. A Middle English herbal, reconstructed from various manuscripts. Upsala-Copenhagen-Cambridge (Mass.): A.-B. Lundequistska Bokhandeln-Ejnar Munksgaard-Harvard University Press.

Cockayne, O. (ed.) (I864-I866). Leechdoms, wortcunning, and starcraft of early England. London: Longman. 
Chantraine, P. (I999). Dictionnaire étymologique de la langue grecque. Histoire des mots. (2nd ed.) Paris: Klinksieck.

Felter, H.W., \& Lloyd, J.U. (I905). King's American dispensatory. (I9th ed.) Cincinnati: The Ohio Valley Company.

Font Quer, P. (I987). Plantas medicinales. El Dioscórides renovado. (Ioth ed.) Barcelona: Labor.

Fortes Fortes, J. (I984a). Fitonimia griega I. La identificación de las plantas por los fitónimos griegos. Faventia, 6:1, 7-29.

- ( ( $984 \mathrm{~b}$ ). Fitonimia griega II. Las fuentes del vocabulario fitonímico griego. Faventia, 6:2, 7-I 5.

García Valdés, M. (ed.) (I998). Plantas y remedios medicinales (De materia medica). Madrid: Gredos.

Halliwell-Phillipps, J.O. ( ( 889). A dictionary of archaic and provincial words, obsolete phrases, proverbs and ancient customs from the fourteenth century. (I Ith ed.) London: Reeves and Turner.

Hunt, T. (I989). Plant names of medieval England. Cambridge: D. S. Brewer.

Kurath, H., Kuhn, S.M., Reidy, J., \& Lewis, R.E. (eds) (I954-200I). Middle English Dictionary. Ann Arbor: University of Michigan Press.

Martin, W.K. (1965). The concise British flora in colour. London: Ebury Press and Michael Joseph.

Mattioli, P.A. (I558). Commentarii secundo aucti, in libros sex Pedacii Dioscoridis Anazarbei De medica materia. Venetiis: Ex Officina Erasmiana, Vincentij Valgrisij.

McCarren, V.P. (I998). Editing glossographical texts: to marrow and to marrow and to marrow. V. P. McCarren \& D. Moffat (eds) A guide to editing Middle English. Ann Arbor: University of Michigan Press, I4I-55.

Moreno Olalla, D. (2002). Lelamour's Herbal (MS Sloane 5, ff. I3-57). Critical edition and philological study. (Ph.D. University of Málaga PhD dissertation), Universidad de Málaga, Málaga.

- (2007). The fautys to amende. On the interpretation of the explicit of Sloane 5, ff. I3-57, and related matters. English Studies, 88:2, I I9-I42.

- (2013a). A plea for ME botanical synonyma. V. Gillespie \& A. Hudson (eds) Probable truth. Editing medieval texts from Britain in the twenty-first century. Brussels: Brepols, 387-404.

- (2013b). The textual transmission of the Northern Macer tradition. English Studies, 94:8, 93 I-957.

Mowat, J.L.G. (I887). Alphita. A medico-botanical glossary from the 
Bodleian Manuscript, Selden B.35. London-Oxford: Henry Frowde-Oxford University Press.

Prior, R.C.A. (1863). On the popular names of British plants, being an explanation of the origin and meaning of the name of our indigenous and most commonly cultivated species. London: Williams and Norgate.

Simpson, J.A., \& Weiner, E.S.C. (eds) (I989). The Oxford English dictionary. (2nd ed.) Oxford: Oxford University Press.

Turner, W. (I 55 I). A new herball, wherin are conteyned the names of herbes in Greke, Latin, Englysh, Duch Frenche, and in the potecaries and herbaries Latin, with the properties degrees and naturall places of the same. London: Steven Mierdman.

Whytlaw-Gray, A. (I938). John Lelamour's translation of Macer's Herbal. (M.A. University of Leeds MA dissertation), University of Leeds, Leeds. 